Pecvnia, 9 (2009), pp. 181-204

\title{
Crisis of Corporate Social Responsibility and its Status in Russia
}

Recibido: Junio 2009

Aceptado: Octubre 2009

\author{
Vitaly J. Ozira \\ vozira1@yandex.ru \\ International University of Moscow \\ 17 Leningradsky prospect \\ 125040 Moscow (Russia)
}

En este trabajo se enfoca la crisis financiera global con el fin de destacar los problemas más importantes relacionados con ésta. La presente crisis no fue provocada por causas meramente económicas. La causa fundamental radica en el liderazgo. A veces, la gente olvida que la ética de las relaciones juega un papel importante a la hora de llevar a cabo un negocio.

Últimamente, no obstante, se presta más atención al aspecto positivo de la ética profesional. Un número creciente de gestores rusos emprenden el camino en el que los valores positivos conducen a un eficaz funcionamiento diario así como su prestigio y sostenibilidad a largo plazo.

A diferencia de la concepción de la Europa occidental y escandinava de Responsabilidad Social Corporativa, en la Europa Central, del Este y en Rusia, es un concepto relativamente nuevo. Sin embargo, las divergencias culturales que constituían
This paper picked a topic - the global financial crisis - to highlight several related problems. The current crisis was not caused by failed economic policies. The root cause is failed leadership. People sometimes forget that business ethics at its core is about excellence and high attainment rather than misdeeds and malfeasance.

In recent years, however, more attention has been paid to the positive side of ethics. More managers in Russia are waking up to the ways in which positive values contribute to a company's effective day-to-day functioning, as well as its reputation and long-term sustainability.

Contrary to Western Europe and Scandinavia, Corporate Social Responsibility is a relatively new concept in Central and Eastern Europe and Russia. Cultural gaps between Westerners and Locals have gradually been 
un obstáculo serio entre los inversores occidentales y locales en los últimos años se han reducido. Los inversores extranjeros van mejorando su conocimiento de como actuar con éxito en una región postcomunista. Los puentes que se han tendido entre el Este y el Oeste han reducido los riesgos de joint ventures.

Las opiniones expresadas en el articulo son responsabilidad del autor y no deben interpretarse como la postura oficial rusa sobre la Gobernanza Corporativa.

Palabras clave: Liderazgo; Responsabilidad social corporativa; Destrezas de razonamiento ético; Riesgo de gestión. narrowing and becoming less divisive. Improved knowledge by foreign investors on how to operate successfully in a post-communist region, on "how to bridge the gap", greatly decreases the risk of the East-West joint venture.

The views expressed in the paper are the author's own responsibility and should not be interpreted as presenting the official position paper on Corporate Governance.

Key words: Leadership; Corporate Social Responsibility; Ethical reasoning skills, Risk management.

1. UNDERSTANDING THE CONCEPT OF CORPORATE SOCIAL RESPONSIBILITY

\section{Introduction}

After 20 years of political, social and economic turbulence, uncertainty and stagnation, transition countries, are finally moving to offer promising opportunities to those Westerners who can master the art of bridging the troubled waters left in the wake of the Cold War.

The current crisis was not caused by subprime mortgages, credit default swaps, or failed economic policies. The root cause is failed leadership. New laws, regulations, and economic bailouts won't heal wounds created by leadership failures. They can only be solved by new leaders with the wisdom and skill to put their organizations on the right long-term course ${ }^{1}$.

Business leaders are admired yet often distrusted, and the idea of management as a profession is similarly on shaky ground-as it has been for more than 100 years. The situation may be due in large part to the role of university-based business education from the founding of the Wharton School in 1881 and continuing right up to the present. 
Corporate officers and directors are legally required to act in the best interests of the corporation. Contrary to popular belief, this does not mean maximizing shareholder value without regard for the effect on employees, customers, suppliers, the environment, or the communities in which the corporation does business.

Business ethics, of course, is as old as business itself, but formal academic study of the subject is comparatively new. Given the field's origins in these events, people sometimes forget that business ethics at its core is about excellence and high attainment rather than misdeeds and malfeasance. The issues span the ethical spectrum: falsified books and records, misleading communications, defective and dangerous products shipped without warnings or information, abusive behavior and unsafe conditions in the workplace, unwarranted favoritism and conflicts of interest, myriad examples of bribery and extortion, unfair and predatory competition, theft and misappropriation of information, civic and environmental irresponsibility.

Unfortunately, we have no reliable gauge of how the levels and types of misconduct have changed over time. One reason for this is that expectations for corporate behavior are constantly evolving. Conduct that would have been ethically acceptable in one era becomes unacceptable as expectations rise.

The most noteworthy message of the Enron trial is that corporate executives can be convicted in a court of law for a pattern of deception that may or may not be illegal. Left unaddressed in the trial were many financial transactions and accounting decisions of debatable legality. The prosecution chose to avoid a scholastic examination of these mind-numbingly complex maneuvers and Enron's observance of equally complex Generally Accepted Accounting Principles and SEC rules.

Following the lead of federal prosecutors, the jury resoundingly concluded that in determining guilt or innocence in cases of corporate fraud, considerations of intent dominate the details of compliance or non-compliance with arcane legal rules.

The General Motors (GM) bankruptcy also poses several questions. How did the board and management of a great company ever allow this extraordinary situation to develop? It is easy to point to the labor agreements from the 1950's, and the slow response to the superior engineering and manufacturing of Japanese competitors, and a reluctance to take environmental issues seriously. But these were not overnight 
developments. Beyond that, did GM's financial controls become too powerful a force for the product engineers to overcome? Did the marketers not see what Toyota was doing with the Camry and Lexus? On another front, what does it mean for the US government to be supporting one competitor against a group of healthy rivals? Is that what the bankruptcy laws were designed to accomplish? Doesn't a healthy industry require less capacity, so that the winning companies can actually prosper? The US administration is embarking on an interesting experiment in political economy.

People sometimes forget that business ethics at its core is about excellence and high attainment rather than misdeeds and malfeasance. Moreover, new issues are constantly coming to the fore as a result of changes in technology, society, and politics. For instance, data privacy was not a major issue until the late 1980s and 1990s when companies began to exploit newly available information technologies. Recent advances in biotechnology have raised ethical issues that have never before presented themselves. And globalization has given rise to cross-cultural dilemmas that just weren't a major part of the scene in the 1970s.

The paths to values are many and varied. Some managers arrive by way of a crisis or scandal, and others by way of personal conviction or a logical process of reasoning and analysis. And a few are motivated simply by the vision of a better and more humane way of conducting business.

Overall, though, our experience has been that probably half, and maybe even two-thirds, categorize ethics mainly as a risk management issue. These managers tend to see corporate values as a tool for preventing misconduct with its incident legal, financial, and reputational risks. Ethics gets their attention because they want to avoid the high-profile missteps and billion-dollar losses experienced by a Salomon Brothers, Bridgestone/ Firestone, or Enron.

In recent years, however, we have seen more attention being paid to the positive side of ethics. More managers in Russia are waking up to the ways in which positive values contribute to a company's effective day-to-day functioning, as well as its reputation and long-term sustainability. In this paper, we trace these connections in some detail and show how they play out in practice.

In the future, we think more managers in Russia will recognize that risk management is only part of the story and that the benefits of positive values go well beyond problem avoidance. I have seen this 
progression in some companies that initially turn to values as a damage control measure when confronted with a scandal in their organization or industry. Then, over time, they come to take a broader view as they see the positive effects on work life, product quality, relationships with their constituencies, or their standing in the community.

To some of the ways positive values can add to the bottom line. And research points to others that we discuss here-better access to talent, enhanced employee commitment, better information sharing, greater creativity, enhanced reputation, and so on.

But we should caution managers against focusing only on the financial case for values. No matter how much evidence we amass for this case, the fact remains that moral indifference and even blatantly unethical behavior can also be financially rewarding in many circumstances. We should not forget that slavery had its financial benefits for slave owners. And, in virtually every case of misconduct that we have studied, the perpetrators justified their actions by reference to the anticipated financial gains.

What's important to recognize is that today's in Russia companies are being held to a higher standard. Financial results are a must, but in addition, leading companies are expected to achieve those results by acting in an ethically acceptable manner. This shift in our understanding of the corporate personality has profound implications for management in Russia. Among other things, it means that managers must develop more robust ethical reasoning skills and increasingly subject their decisions to ethical as well as financial analysis. In a world in which companies are expected to behave as moral actors that conform their activities to certain ethical requirements, financial tests of acceptability alone are insufficient.

This is an inherently challenging task in any country, but it is more difficult in some environments than others, particularly those plagued by high levels of corruption. The effects of corruption are insidious and they go well beyond requests for bribes and favors. Obviously, the economic implications can be significant when your competitors can get away with paying off officials-either public or corporate-to win major contracts or secure exemptions from health, safety, or other requirements.

In general, though, it is easier to meld ethical commitment and economic success in environments where information is free-flowing 
and people have real choices about where to work, invest, and consume. Of course, people can only make sound choices if they are educated and have ongoing access to relevant information. In addition, a well-understood ethical framework and an effective legal system are crucial. In other words, it is very hard to talk about corporate ethics without paying attention to the broader social and institutional context in which a company is operating.

Sustainability is an issue that the world has to face today in the situation of growing population, increasing social disparities and the scarcity of resources that come along with the benefits that globalization brings. Corporate Social Responsibility (CSR) has been regarded as the business contribution to sustainable development and is thus one of the topics covered more often than before in the agendas of the world economic and social forums.

In 2009 Russia's energy giant Gazprom cut off its supply of natural gas to Ukraine's energy company in the depths of winter. The move confirmed the fears of many in the West that the wounded Russian bear, smarting from its diminished role in the post-Soviet era, could be a cruel and dangerous troublemaker. With about one-quarter of the world's reserves of natural gas, Russia was judged to be using its energy resources to beat up on a helpless neighbor and to flex its geopolitical - and potentially expansionist - muscles. "The Western notion that Russia uses energy as a weapon is a media oversimplification of very complicated politics," says Harvard Business School (HBS) professor Rawi Abdelal. Abdelal, who recently produced a three-part case on Gazprom, says the 2006 Ukraine cutoff was in reality a business decision, albeit an extreme one. The context for that incident between the two countries went back years and involved at least one previous shutdown over unpaid Ukrainian bills, as well as disputed pipeline fees, unsigned contracts, bad faith, and, ultimately, failed negotiations. Although other neighboring countries had had similar problems with Ukraine, the shutoff was a PR disaster for Gazprom, which had enjoyed a long-standing reputation as a reliable supplier of natural gas, through pipelines in Ukraine, to Europe.

CSR has offered heavy debates among businesses and social and political communities, highlighting both pro and counter argumentsthese starting with the essential question about the role of business. Is it just to attain profits or is it to contribute to the wider development of the community? Is taking responsibility for something "extra" the company has to commit to or could it rather be perceived as a way of doing 
business? Does engaging in CSR make business sense, and if so, how should it be best managed on the strategic and operational level?

The current paper has been prepared on the basis of various sources. Among key sources the author have also used Harvard Business School case study. HBS has begun reevaluating its practices after drawing fire for the high-profile role its graduates have played in an unprecedented financial crisis that some allege stemmed from recklessness or negligence.

The case study-being written by a task force formed in November 2008 by HBS Dean Jay O. Light to research the implications of the financial crisis for HBS-will analyze the School's performance in preparing students during the lead up to the financial crisis.

A spate of business scandals - from Enron's spectacular collapse to stock option backdating - have put business schools on the spot to explain what, if any, responsibility they might have for what's gone wrong in America's executive suites. Two theories have emerged. The wrongdoers were just a disparate collection of lone bad actors on the corporate stage. Alternatively, the scandals reflected something systemic and pervasive in American business culture, with the trail winding its way back to business schools.

In his new book, From Higher Aims to Hired Hands: The Social Transformation of American Business Schools and the Unfulfilled Promise of Management as a Profession (Princeton University Press), HBS associate professor Rakesh Khurana builds a case for the systemic argument ${ }^{2}$. He also explains how business schools have evolved over the past century, in many cases drifting from their original intent of making management a profession, with a commitment to using a body of knowledge for the good of society. Khurana writes that... the university-based business school of today is a troubled institution, one that has become unmoored from its original purpose and whose contemporary state is in many ways antithetical to the goals of professional education itself.

Today, we take managers for granted. But 100 years ago, they were fresh recruits in the inexorable march of industrial capitalism. In a grand experiment to turn management into a legitimate profession,

2 Rakesh Khurana (2007) From Higher Aims to Hired Hands: The Social Transformation of American Business Schools and the Unfulfilled Promise of Management as a Profession. Princeton, N.J.: Princeton University Press. 
universities invented the modern business school. Questions raised then about such schools' purpose remain strikingly fresh today.

When they first emerged, business schools were highly controversial institutions. The profit-maximizing imperatives of business were seen to be at odds with the more disinterested mission of universities. Business education came to be an accepted and uncontroversial part of the university only through the efforts of a vanguard of institutional entrepreneurs, both academics and managers, who saw the need for creating a managerial class that would run America's large corporations in a way that served the broader interests of society rather than the narrowly defined ones of capital or labor.

In 1926, C.P. Biddle, an assistant dean at Harvard Business School, provided one framing of what was, at the time, the highly contested question of whether and why business schools belonged in universities: The interests of the shareholders are primarily measured in purpose of the graduate training. If its purpose is to train "hands," or technicians, or merely successful money-makers, in my judgment the course has no place in a graduate department of a university. On the other hand if its purpose is to train "heads" or future leaders in business, it has no difficulty in justifying its existence or place.

Although the choice for business schools that Biddle presented nearly a century ago has yet to be decisively made, a number of factors suggest that all is not well within the institution of the university-based business school: recent events and trends in the corporate world; a mounting chorus of criticism directed at business schools from within their own ranks; and the implicit challenge represented by the rise of forprofit, online, and other alternatives to the traditional MBA. Biddle's implicit question is as relevant today as it ever was. For business schools and for management itself, the times seem ripe for reopening the question of what exactly this institution is for, what functions we as a society want it to perform, and how well it is performing them.

\section{Great Depression Rekindles the Drive for Professionalism}

Sixteen business school deans, including Edwin F. Gay of HBS, founded the American Association of Collegiate Schools of Business in 1916 to set standards for the professionalization of business education. Years passed with no consensus, but the Great Depression revived interest 
in setting standards to educate managers with a strong sense of social and ethical obligation.

Business school deans [in the early 1930s] were determined to finally reach a working consensus about what constituted a professional business education, and to mobilize their institutions on behalf of a nation whose core political and economic institutions were being reexamined. From this process a unanimous consensus emerged: business schools could no longer hope that their students would recognize the social significance and relations of business once they became managers. The schools themselves were ultimately responsible for instilling in students an understanding of the responsibilities of business for the well-being of society. University of Illinois Professor Hiram T. Scovill noted that the best way for schools of business to justify their existence in view of the apparent ills and evils in business in the past is to train the businessmen of the future so that they will recognize their obligations to society.

As in the 1920s, however, the strongest public advocate for professionalization in the most comprehensive sense of the term was HBS Dean Wallace B. Donham, who was appalled by the lack of national leadership from corporate executives in the midst of the Depression. As a result, Donham in the early 1930s renewed and elaborated his previous calls for business schools to aid in transforming management into a profession - not a mere technical specialization or guild, but rather a group self-consciously dedicated to the service of society. Donham now declared that in institutions (such as his own) that called themselves schools of "business administration," too much emphasis had been placed on the first of these two words and too little on the second. Administration, he said, required managers to focus on "the human aspects of organization." Neither organization charts nor the "grossly misleading" application of economics to the management of business firms could be relied upon to give satisfactory administrative results.

\section{The Fall of Managers}

Beginning in the early 1970s, the United States entered an extended period of economic distress for which critics blamed corporate managers, who were characterized in the media as "unaccountable plutocrats." Out of this economic turmoil emerged a new view of American capitalism. So-called agency theory, developed and promoted by leading academics at American business schools, recast management 
as an agent of shareholders and a servant to share price. Other stakeholders, such as workers and communities, no longer mattered.

The rise of agency theory and its dissemination in business schools reflected, among other things, the revolution in ideas about management and the purpose of the corporation that came with the emergence of investor capitalism in the 1970s. HBS professor emeritus Michael Jensen pointed to the publication in the New York Times Magazine in 1970 of an article on the purpose of the corporation by University of Chicago economist Milton Friedman as both a sign of growing academic skepticism about managerialism and an important cultural event in its own right. In his article, Friedman argued that the sole concern of American business should be the maximization of profit, since the existing system, in his view, was one of accommodation to a host of conflicting interests, an arrangement that damaged society's economic well-being.

The agency theorists had a broad impact on corporate policy and, in particular, on a fundamental redefinition of the purpose of the corporation by executives themselves. Agency theory dissolved the idea that executives should be held - on the basis of notions such as stewardship, stakeholder interests, or promotion of the common good to any standard stricter than sheer self-interest. How could they be if they were incapable of adhering to such a standard in the first place? Students were now taught that managers, as a matter of economic principle, could not be trusted.

In rejecting the managerialist ideology that had become the central justifying rationale for the existence of business schools in the years since the end of World War II, agency theory also served to delegitimate managerial authority itself. This was a striking development to have occurred in university business schools, which owed their original raison d'etre to their ascribed role of legitimating managerial authority in the late nineteenth and early twentieth centuries. It represented, within the confines of a "professional school," a thorough repudiation of professionalism as that notion had been understood in the founding era of American business schools.

The Rise of Leadership as a Mission

With the demise of managerialism, do business schools retain any genuine academic or societal mission? 
By the beginning of the 1990s, business schools - particularly those elite schools that had staked their reputations on academic superiority - faced a full-blown crisis of identity and purpose. It was no longer possible for business schools to tout a mission of educating managers according to the canons of postwar managerialism, for traditional managers had been successfully portrayed by the takeover artists and shareholder activists of the 1970s and 1980s, as well as by business school professors influenced by the work of scholars such as Oliver Williamson and Michael Jensen, as incompetent at best, and venal and untrustworthy at worst. Moreover, increasing numbers of students at the most prestigious schools now shunned traditional management careers altogether in favor of fields like consulting and investment banking. Faculty at the elite business schools were thus educating fewer future managers, which left them increasingly ambivalent and uncertain about what they were educating students for.

A seminal article appeared in the May-June 1977 issue of Harvard Business Review by Harvard Business School Professor Abraham Zaleznik, titled "Managers and Leaders: Are They Different?" "Managers and leaders are very different kinds of people," Zaleznik wrote, giving rise to a conceptual distinction that has proven both popular and enduring.

Eventually business schools began responding to the clarion call for developing leaders, not managers. In the early 1990s, for example, Harvard Business School formally shifted its focus from its traditional concern with general management, issuing a new mission statement that described its purpose as "to educate leaders who make a difference in the world. A crucial question raised by business schools' substitution of the leadership paradigm for the managerial one is whether the former constitutes an adequate foundation for a university-based professional school.

\section{The Challenge Ahead}

The downfall of managerialism, in the business world and in business schools, and its replacement by the ideologies of shareholder primacy and managers as the fallible, indeed eminently corruptible, agents of shareholders, have not only severely eroded the cultural authority of managers that the creators of the university business school sought to establish and uphold. With the abandonment of the professionalization project and the idea that managers - not shareholders, labor, the state, 
or the market - should exercise ultimate control over the corporation, university business education lost the grand narrative that had sustained it from its beginnings. The effects of this loss, in turn, are visible all around those of us who teach in business schools today.

Schumpeter, one of the 20th century's eminent economists, believed that capitalism sowed the seeds of its own destruction. Its chief virtue was long-term - the capacity to increase wealth and living standards. But short-term politics would fixate on its flaws - instability, unemployment, inequality. Capitalist prosperity also created an oppositional class of "intellectuals" who would nurture popular discontents and disparage values (self-enrichment, risk-taking) necessary for economic success.

Almost everything about Schumpeter's diagnosis rings true, with the glaring exception of his conclusion. American capitalism has flourished despite being subjected to repeated restrictions by disgruntled legislators. Consider the transformation. In 1889, there was no antitrust law (1890), no corporate income tax (1909), no Securities and Exchange Commission (1934) and no Environmental Protection Agency (1970).

Some guesses about capitalism's evolution seem plausible. The financial industry - banks, investment banks, hedge funds - will shrink in significance. Regulation will tighten; required capital will rise. Profitability will fall. (Until recently, finance represented 30 percent or more of corporate profits, up from about 20 percent in the late 1970s.) More of the best and brightest will go elsewhere.

But Schumpeter's question remains. Will capitalism lose its vitality? Successful capitalism presupposes three conditions: first, the legitimacy of the profit motive - the ability to do well, even fabulously; second, widespread markets that mediate success and failure; and finally, a legal and political system that, aside from establishing property and contractual rights, also creates public acceptance. Note that the last condition modifies the first two, because government can - through taxes, laws and regulations - weaken the profit motive and interfere with markets.

The central reason Schumpeter's prophecy remains unfulfilled is that U.S. capitalism - not just companies, but a broader political process - is enormously adaptable. It adjusts to evolving public values while maintaining adequate private incentives. Meanwhile, the striving character of American society supports an entrepreneurial culture and work ethic - capitalism's building blocks. As for new regulations, many 
don't depress profitability because costs are passed along to consumers in higher prices.

It's also wrong to pit government as always oppressing business. Just the opposite often holds. Government boosts business.

Government inevitably expands in times of economic breakdown. But there is a thin line between "saving capitalism" from itself and vindicating Schumpeter's long-ago prediction.

\section{The Myth of Laissez-Faire}

Even as government intervention and regulation are looming large in the United States, one is still pulled up short on encountering Jeff Madrick's new book, The Case for Big Government ${ }^{3}$.

And when he says big, Madrick, editor of Challenge magazine and a senior fellow at the New School's Schwartz Center for Economic Policy Analysis, means big.

Big government works, Madrick asserts, the economies of nations with high taxes and big governments have grown rapidly, are highly productive, and provide their citizens with a standard of living every bit the equivalent of America's and some argue superior to it.

He points to Sweden, Germany, France, the Netherlands, and Norway as exemplars and promotes the research of economist Peter Lindert of the University of California, Davis.

Madrick advocates big government not because it's big but because it's powerful enough to manage change in an increasingly complex world.

\section{Defining Corporate Social Responsibility}

There has been considerable discussion about the essence of Corporate Social Responsibility (CSR) in its current meaning over recent decades. The profit seeking private sector has served as a powerful development engine that has affected progress in most areas of society. If

3 Jeffrey G. Madrick (2009) The Case for Big Government. Princeton, N.J.: Princeton University Press. 
we turn our focus to the inadequacies of this development, questions arise about the cost; while companies are the source of such development, more information is required about where this is all leading.

Issues such as the unequal distribution of welfare, environmental concerns, crises concerning values and many other similar problems are shared by most levels of society. What role should enterprises perform in responding to these challenges and what problems should business organisations take responsibility for.

From these definitions, the following key features of CSR may be concluded: Voluntary - it is voluntary action performed by companies that goes beyond simple legal compliance; Core aspect of business- it is applied to all business activities throughout the company; In broad categories it comprises social, environmental and financial responsibility-also known as the Triple Bottom Line-being a framework for measuring and reporting corporate performance against economic, social and environmental parameters.

In addition to the benefits raised by Business for Social Responsibility, there is often also the advantage of risk management. Responsible employment practices, product quality control and environmental standards protect a company from costly litigation and the damaged reputation that can follow. Good social performance may reduce pressure on governments to regulate a sector or business. Good management practices also shield a company from scandal and factor price instability.

2. A REGIONAL AND COUNTRY PERSPECTIVE - CORPORATE SOCIAL RESPONSIBILITY IN CENTRAL AND EASTERN EUROPE AND IN RUSSIA

Contrary to Western Europe and Scandinavia. CSR is a relatively new concept in Central and Eastern Europe (CEE) and Russia. These are countries that have experienced rapid changes over the past 20 years while moving from planned economies to market economies, building democratic institutions and societies. While some have taken a strong leap ahead with their reforms, others have faced more challenges in managing the economic and social changes.

The gap to be bridged in this case is not only the one of culture, and historical hostilities, but especially of ingrained business values, 
processes and practices. Western firms are run with sets of practices that have been hammered out over many years on a trial and error basis by competitive market challenges within the framework of tested legal and institutional rules as well as informal checks and balances. On the other hand the business practices in emerging markets have developed in a state monopolistic context without competitive tensions, where the priority of the state was placed not on profitability or customer satisfaction, but on maximum production and on job security, while the priority of the managers was placed on building their personal power and careers. Enterprises managed in this way are in no shape to face international competition. The chief challenge for Westerners is to rapidly transfer the competitively tested best practices of western firms to their local investments, so that substantial value can be added by improving efficiency, quality and market share. These transfers of knowledge are very hard to achieve as they involve a displacement of many deeply ingrained working habits and processes as well as rapid learning of 'new' ones.

At the results of the economic crisis the negative effects of the changes have also become more visible in all CEE countries. Rising unemployment, inflation and social exclusion among many others factors are just some of the challenges that governments, civil institutions and the private sector in these countries have to face.

Market-oriented institutions in these countries are often fragile and in some cases non-existent, and corruption hampers reform efforts. A general mistrust of the private sector, inadequate physical infrastructures, environmental problems and low standards of corporate transparency and accountability, in addition to the need for public sector reform are some of the difficulties in the region.

The subsequent need for rapid transition and the unprecedented scale of industrial restructuring and privatisation are among the main causes for the following:

- High social costs - unemployment, corruption, the need for social protection, lack of social provision for vulnerable groups.

- Health problems - a decline in the quality and scale of healthcare, falling life expectancy, an unhealthy workforce.

- A mistrust of large corporations and foreign investors and a lack of understanding on both sides of how business can add value. 
There are many contextual factors, both pro and con, to be taken into account before a Westerner undertakes to invest in this region. First the negatives:

- Despite considerable efforts to rationalise the business environment and despite some progress in this area, institutions, laws and bureaucratic procedures continue to be out of tune with the business environment of a traditional western market economy. Public bureaucracy at all levels (central, regional and municipal) remains heavy handed, inefficient and corrupted. Most vexing for the western businessman is the excruciatingly slow pace of bureaucratic procedures. Add to this that laws and regulations suffer from lack of precision, are often contradictory, differ by level of bureaucracy (from central to regional to municipal) and have a long history of instability. One problem area where progress is being made is the instability and ambiguity of laws and regulations. The priority which the countries of the region give to cooperating closely with and eventually being admitted to the EU and the terms of the accession agreements the countries are required to accept, has a stabilizing effect since it provides a powerful motive for these countries to render their institutional structure compatible with that of the EU.

- Corruption and the inextricable entanglement of the old elites with power remain pervasive at all levels of the bureaucracy. It would take a substantial rise in the salaries of public servants to start tackling this problem. Even then corruption would most probably persist. It is embedded in a multiplicity of informal networks, at times extending into the underworld. Experience in other countries has shown that such networks are notoriously difficult to dismantle.

- Foreign investors now have no problem obtaining the convertible currency that they need from within the countries of the region. However, as long as most local currencies continue to devaluate, even if gradually, currency rate issues are apt to remain a major headache for foreign investors and to affect profitability adversely.

Now, to the positives:

- In terms of profit opportunities this can be called a "golden period" of the region. 
- The markets remain largely unsaturated. This means, among other things, that even in areas where competitors have already stepped in, the opportunities for a new brand to get a large share of the market remain substantial. In a "brand-virgins" market there are no entrenched brand loyalties. And new opportunities for investment arise as the markets in the region continue to mature. Increasingly the needs for basic consumer goods are being met but as the middle classes expand, demand for more sophisticated goods and services rises.

- Competition is still weak. Local competition cannot easily get off the ground both because of a lack of managerial know-how about market economies and because the sources of financing are still in short supply. In a business environment geared to payments in cash, credit is extremely difficult to obtain. A foreign investor has a major competitive advantage here since, unlike a local entrepreneur he is able to grant credit terms. Vis a vis the Locals the foreign investor is in a very advantageous position both on the grounds of technical and managerial expertise and on the grounds of financial strength.

- An obvious current advantage compared with the recent Soviet past is the ready availability of imports as needed for raw materials and components. For the Locals, imports have transformed the traditional shortage scene of the Soviet era. Now there are plenty of goods but an asphyxiating shortage of cash. Substantial improvements of communications facilities and of computer resources have also been made.

- Cultural gaps between Westerners and Locals have gradually been narrowing and becoming less divisive. A process of "marketization" has been going on for the past decades among managers in region that makes things easier for Westerners in many fairly obvious ways. On the other hand, it is important for Westerners to be aware that this process is very uneven. The scope and depth of "marketization" varies very greatly as between individual managers. Furthermore even "marketized" managers retain important elements of their pre-existing culture that complicates effective communication.

- What remains a major impediment to effective interaction are stereotypical misconceptions that each side holds about the other. Such stereotypes consist of particular characteristics which each 
side attributes to the other (typically, Westerners are deemed 'insensitive' 'arrogant' 'controlling' 'fearful of taking risks' 'naive' 'cold profiteer'. Russians are deemed 'unreliable' 'thick' 'secretive' 'ignorant' 'dodgy' 'irrational'), and each side's notions about how the other side perceives them (Typically: Locals say, "Westerners think us stupid", "don't trust us", don't respect us, "lay down the rule without any understanding of the real difficulties"; Westerners tend to say of Locals, "they wait for us to solve all their problems", "shirk responsibility", "are unable to understand").

- Such stereotypes operate as distorting lenses through which interacting partners perceive and interpret one another's actions. Like all stereotypes they are very resistant to change. Partly because like all stereotypes they contain a measure of truth, albeit distorted and out of proportion, and partly because like all stereotypes they are not simply dispelled by experience since, as is well known, people tend to interpret their experience to fit their prejudice rather than the other way around. It requires well planned deliberate measures by management to create environments of interaction which will dispel such misconception and clear the air for effective cooperation.

- Improved knowledge by foreign investors on how to operate successfully in a post-communist region, on "how to bridge the gap", greatly decreases the risk of the East-West joint venture ${ }^{4}$.

Any western investor, before undertaking to invest in the region, would be well served by carefully thinking through a complete strategy. One of the main insights gained from CC's experience is that, contrary to prevalent thinking, western investors should use the same planning elements as would be suitable in investments in the West and/or in joint ventures with western partners. This would involve thinking out the mission of the newly formed enterprise, its more immediate goals, the organizational form that would work effectively, the needed organizational culture and the process that will be effective for the execution of the strategy.

4 Paul R. Lawrence and Charalambos A. Vlachoutsicos (2003) "Bridging Over Troubled Waters", Harvard Business School Working Paper, 04-022. 
All this is done as a matter of course for investments in western markets, so that it may well sound obvious to western senior managers that this approach needs to be adopted also for investments in transitional economies. But how can Westerners apply this overall approach in practice? How can they ensure that each strategic element is fashioned and applied in the light of the business realities and managerial practices prevalent in the post-communist region, and how, most particularly can they pinpoint what will need to be changed to achieve the desired results? We will consider each of these strategic elements briefly and then focus in some detail on the execution process that needs to be followed in order to succeed.

Mission: To add substantial value by building strong firms able to survive and prosper long-term in the distinctive business environment of the region and also able to face global competition. This is the explicit mission of all CC's joint investments. They are not 'hit and run' projects. Making this seemingly obvious statement serves to drive home the point that, even though local firms may have come a long way adjusting to the free market since the days of state monopoly, locals still have a long way to go in this direction, if business projects involving long-term cooperation with Westerners are to become truly viable.

At the same time, it must be emphasized, that local firms have been able to survive in their historical environment and that environment is still present in many respects, albeit in varying degrees. On no account should Westerners forget that the incumbent local management has business experience, know-how and trusted networks that will still be essential for the success of the new investments. In fact, along with cheap assets, the need for this local know-how, this street smarts if you will, may well be the main reason why a number of western firms moving into so unfamiliar a turf favor the joint venture or acquisition approach over the green field approach. The art, or skill, of fulfilling the enterprise's mission consists in finding ways to precipitate and implement drastic changes required without losing out on its current strengths.

Goals: The essence of the typical investment opportunity in the region is the opening for quickly adding value to the local firms existing product-service line of business enabling it to achieve a large market share in a growing market. All this can be done most readily by introducing the business methods that support efficiency, product design 
and quality and marketing results that have been tested for their effectiveness in the competitive trial and error process of the western market place. This means that a great many tested western business practices will need to be rapidly put in place in the new firm. This was true in the case of Titan; the new venture's goal was very explicitly to rapidly add value. This particular goal will have critical implications for the next three strategic elements, organizational form, culture and implementation.

Organizational Form: An organizational structure that can deliver on the Mission and Goals stated will clearly need to be one that can best handle rapid change and rapid learning. The evidence from organizational research shows that such an organization needs to be (1) relatively flat to avoid the stabilizing, even stagnating, effects of a multitiered hierarchy, (2) relatively egalitarian to avoid the barriers to change and learning created by significant status differences and multiple barriers, and (3) open to lateral problem-solving to avoid the 'silo-effect' caused by strong employee identification with functional hierarchies of the overall organization. Clarifying these requirements demonstrates the magnitude of the contrast with the customary organizational practice in the region where multi-tiered hierarchies with sharp status differentiation and tight defensive functional group loyalties are characteristic. The Soviet system generated highly authoritarian systems with strong vertical chains of command.

Culture: The requirement for rapid change and learning in the new venture will, as indicated by organizational research also set-ups the need to develop a business culture that stresses the values of equivalence and openness between all members and all sub-groups of the organization.

Westerners need to get an accurate feel for the significant magnitude of these cultural changes. Nevertheless, there are visible signs of the CSR concept becoming more known in the region. Large, mainly multinational companies have started to adopt their corporate CSR policies and programs in the local context. Foreign investments have encouraged a rise in the CSR agenda. Business leaders have more often than before started to at least talk about whether CSR contributes to business success-understanding that although the primary focus of business is to generate profits, corporations can at the same time contribute to 
social and environmental goals through applying CSR as a strategic line in their core business practices, corporate governance and management instruments. In a number of countries, forums of business leaders have been created to facilitate the awareness raising process and to share positive examples of CSR.

The most tangible signs of progress can be seen in the "Big Three": Hungary, the Czech Republic and Poland, where large companies and multinational enterprises have been working with local stakeholders and training organizations in order to tackle social exclusion. ABB, Danone, Nestle, DHL, and Johnson \& Johnson are among the many that have contributed to upgrading regional conditions.

The main idea of corporate governance is to ensure that business operates under adequate and meaningful systems keeping in mind the rapid changes in the CEE region. It is also one of the most widely discussed concerns in governments, among business leaders and across society. The exact emphasis on corporate governance issues depends on the specific CEE country, but it is typically an issue confronted in these societies. Generally speaking, for private businesses operating in a market system, the traditional model of governance sees management as solely accountable to investors (shareholders). But a growing number of corporations have been encouraged to consider, and many have accepted, that stakeholders other than shareholders have a legitimate interest in the workings and behaviour of their business, and that the corporation must also be accountable to them. This idea itself is not completely new in CEE countries, but organizations still struggle to apply it to their own circumstances, sometimes because of an incomplete legal framework, which fails to reinforce the application of corporate governance standards.

Environmental protection, which has been at the top of political and business agendas, has progressed remarkably well towards meeting the new requirements. Yet, not all the problems have been solved-a lot of environmental concerns are still to be tackled. CEE countries have inherited a heavy legacy of pollution as a result of an environmental infrastructure that was neglected by the regimes of the past. The greedy and shortsighted engineering practices of the past all but ruined many Russian oil fields: It was routine to pump water in to get oil out, regardless of the consequences. The challenge for current Russian engineers is to coax Russia's shattered geology to cough up more oil - for example, by drilling horizontally, not vertically. That's a tricky technical challenge. While CEE countries will eventually benefit from addressing 
their environmental problems by realizing more efficient industries and creating real benefits (health, amenity) for their citizens, it will take time and effort to achieve such progress.

The third aspect-focus on SMEs-is actually not something characteristic only to CEE. SMEs make up more than $90 \%$ of the businesses in the world, similarly so in Central and Eastern Europe. Developing a sense of environmental and social responsibility is an important issue facing big and small businesses alike. Indeed the understanding of CSR has evolved in recent years and extended its focus to all organizations instead of only spotlighting large multinationals. Further engaging SMEs in social responsibility provides a key opportunity for businesses of all sizes to work together and share best practice along the entire supply chain.

Returning to governance issues, economies in transition often have particularly acute problems with issues of general governance and corruption. In CEE, the speed at which the liberalization of markets occurred, exposed the problem of trying to disregard the previous command and control system without having a new one properly in place. In particular, it highlighted the problems associated with immature legislative and institutional frameworks that helped to fuel such practices. Over the last ten years, many initiatives have been established to pressure and encourage CEE governments to tackle corruption. During the last decade, dramatic new imperatives have emerged for companies to take action against corruption and bribery. Once viewed by many firms as an awkward but necessary requirement of doing business, corruption and bribery are increasingly seen as a form of business malpractice instead. Leading companies, mainly the offices of multinational corporations, have responded to these imperatives by establishing comprehensive codes of conduct, and/or anticorruption and bribery programs that include strong written policies, extensive training, auditing and internal controls.

Within the last 20 years, Russia has undergone a rapid transition. Taking into account the general regional background, it is not surprising that the concept of CSR is only finding practitioners in recent years, after companies have gone through the survival-journey of finding new markets and developing new organisational cultures enabling them to continue their existence. It is only now that CSR is becoming more consciously introduced to business practices, academic curricula and the general public. 
In Russia, as well as CEE in general, companies are trying to adhere to international standards, conventions and guidelines. The regulative frameworks at the state level are aligned with those of the EU.

Western Europe and US companies that have made considerable investments into Russian companies and applied their own standards have largely shaped the local understanding of CSR.

If we look at the future perspectives of CSR in Russia and CEE, it is evident that raising the awareness of the general public, entrepreneurs, consumers. and policy makers is of key importance. Increasing the understanding of CSR, especially of its potential, in both companies as well as the society at large, would on the one hand help create responsible and knowledgeable customers, and on the other, lead companies to become more responsible in their daily business operations, their contact with society and in becoming more environmentally friendly and eco-efficient, Besides the awareness raising and the role of business itself in such progress, there is significant room for the public sector to support the enhancement of CSR in the country.

This paper has studied the state of CSR in Russia by looking at the CSR activities that have attained the most attention, their characteristics and the most common formats of corporate involvement. It was concluded that to a large extent CSR in Russian small and mediumsized enterprises is unconscious and informal. The principal motivation for enterprises becoming involved in CSR includes increasing the satisfaction of employees, contributing to the good image of the company and ethics. As to the obstacles to engaging in CSR, the lack of time and financial resources are seen as the greatest barriers.

The future perspectives of CSR in Russia are largely dependent on direction, policies, guidelines and standards from the state. Recently, a number of initiatives have been undertaken in this area and current trends suggest greater involvement in the coming years. In regard to Russian society in general, raising the general awareness of CSR, NGOs and public sector engagement will be some of the improvements necessary to provide a favourable environment for companies to adopt more responsible practices. 


\section{BIBLIOGRAPHY}

HBS Alumni Bulletin (2008) "Business at the Summit", December.

KHURANA, Rakesh (2007) From Higher Aims to Hired Hands: The Social Transformation of American Business Schools and the Unfulfilled Promise of Management as a Profession. Princeton, N.J.: Princeton University Press.

LAWRENCE, P.R.; Charalambos A. VLACHOUTSICOs et al. (1990) (co-eds.) Behind the Factory Walls. Decision Making in Soviet and US Enterprises. Boston, Mass.: Harvard Business School Press.

LAWRENCE, Paul R. and J.W. LORSCH (1967) Organization and Environment. Boston, Mass.: HBS Division of Research.

- and Charalambos A. VLACHOUTSICOS (2003) "Bridging Over Troubled Waters", Harvard Business School Working Paper, No. 04-022.

MADRICK, Jeff (2009) The Case for Big Government. Princeton, N.J.: Princeton University Press. 